\title{
JEKK \\ Faktor - Faktor yang Berhubungan dengan Status Gizi pada Anak Usia 0-23 Bulan Berdasarkan Composite Index of Anthropometric Failure (CIAF) di Wilayah Kerja Puskesmas Karangayu Kota Semarang
}

\author{
Erlita Nur Andini*, Ari Udiyono*, Dwi Sutiningsih*, and M. Arie Wuryanto* \\ *Bagian Epidemiologi dan Penyakit Tropik, Fakultas Kesehatan Masyarakat, \\ Universitas Diponegoro, Semarang
}

\begin{abstract}
Background: According to UNICEF, half of all deaths of children are caused by malnutrition. The conventional anthropometric index to measure nutritional status is unable to measure the overall prevalence of malnutrition and multiple malnutrition. The solution is to measure it using the Composite Index of Anthropomeric Failure (CIAF). The aim of the study was to analyze the factors that affect the nutritional status of children aged 0-23 months based on Composite Index of Anthropomeric Failure (CIAF).

Methods: This research was an observational analytic study with cross-sectional study design. This research was conducted in the working area of Karangayu Health Center with 231 study sample of mothers who have 0-23 months old children (population used as sample). Chi-square and fisher exact test were used as statistical test.

Result: Factors associated with the nutritional status of children aged 0-23 months based on the Composite Index of Anthropometric Failure (CIAF) were the age of the child ( $p=0,029)$; birth length $(\mathrm{p}=0.005)$; maternal age during pregnancy $(\mathrm{p}=0.002)$; maternal height $(\mathrm{p}=0.025)$; gestational age of maternal $(\mathrm{p}=0.049)$. While factors unassociated were gender $(\mathrm{p}=0.997)$, birth weight $(\mathrm{p}=0.316)$, nutritional status of the mother during pregnancy $(\mathrm{p}=0.232)$, maternal employment $(\mathrm{p}=0.614)$, and education level $(\mathrm{p}=0.951)$.

Conclusion : Age of child, birth length, maternal age during pregnancy, mother's height, and gestational age of maternity mothers were factors associated with nutritional status of $0-23$ months old children based on CIAF. A dominant factor that affected the nutritional status of children aged 023 months was the mother's age during pregnancy.
\end{abstract}

Keywords: multiple malnutrition; anthropometric; CIAF; under 2 year-old

*Penulis korespondensi, erlitanura@yahoo.com 


\section{Pendahuluan}

Status gizi anak merupakan salah satu indikator yang berperan dalam kualitas sumber daya manusia di masa mendatang. Menurut Kementerian Kesehatan Indonesia, status gizi adalah keadaan tubuh akibat konsumsi makanan atau ukuran keberhasilan dalam pemenuhan nutrisi; adanya keseimbangan antara jumlah asupan zat gizi dan jumlah yang dibutuhkan oleh tubuh untuk berbagai fungsi biologis seperti pertumbuhan fisik, perkembangan, aktivitas atau produktivitas, pemeliharaan kesehatan, dan lain-lain. ${ }^{1}$

Dampak yang dihasilkan dari tidak terpenuhinya gizi pada masa krusial tersebut yakni adanya gangguan metabolisme tubuh, mempunyai kecenderungan lebih tinggi untuk terkena infeksi, kemampuan kognitif yang menurun, dan kerugian ekonomi dan produktifitas. Hal tersebut tidak hanya mempengaruhi kesehatan di masa mendatang, tapi juga kualitas dan produktifitas manusia terhadap perekonomian negara. Salah satunya adalah rata-rata kerugian ekonomi di 32 provinsi yang ada di Indonesia sekitar Rp 96 miliar-Rp 430 miliar $(0,15-0,67 \%)$ dari ratarata PDRB provinsi-provinsi di Indonesia akibat stunting. Potensi kerugian ekonomi akibat penurunan produktivitas sekitar Rp 3.057 miliar-Rp 13.758 miliar $(0,040,16 \%)$ dari total PDB Indonesia. ${ }^{2}$

Dilihat dari lingkup global, menurut UNICEF, setengah dari seluruh kematian pada anak balita diakibatkan oleh malnutrisi. Pada tahun 2018 menurut Global Health Nutrition Report, tercatat 150,8 juta anak menderita stunting. Tahun 2000-2018, stunting pada balita didunia menurun dari $32,6 \%$ menjadi $21,9 \%$ dimana jumlah terbanyak di Asia dan Afrika dengan 2 dari 5 anak balita mengalami stunting. $^{3}$ Sekitar 50,8 juta anak menderita wasting dan Asia Tenggara menempati peringkat pertama dengan wasting terbanyak. Lebih dari setengah anak balita dengan wasting terdapat di Asia Tenggara dan seperempatnya berada di Sub-Sahara Afrika. Prevalensi wasting di Asia Tenggara telah merepresentasikan keadaan kebutuhan intervensi gizi yang serius. ${ }^{3}$ Prevalensi underweight menurun setiap tahunnya. Tercatat bahwa pada tahun 2017 prevalensi underweight di dunia mencapai 13,5\%, mengalami penurunan dari tahun 2010 yakni sebesar $16,3 \% .{ }^{4}$ Namun kini, overweight menjadi tren baru dengan peningkatan yang cukup tinggi dengan jumlah 38.3 juta di dunia. ${ }^{4}$ Ditinjau dari tahun 2007 - 2017, kasus overweight di Afrika meningkat dari 6,6 juta menjadi 9,7 juta, begitupun Asia yakni dari 13,9 juta menjadi 17,5 juta. $^{5}$

Di Kota Semarang, prevalensi status gizi balita menurut BB/U dari tahun 2016 - 2017 diperoleh balita gizi buruk 0,38\% (2016) menjadi $0,28 \%$ (2017) dan balita gizi kurang 3,18\% (2016) menjadi 2,19\% (2017). ${ }^{6}$ Wilayah Puskesmas Karangayu diketahui kejadian stunting tercatat terbanyak kedua sebesar $16,27 \%$ setelah Poncol, sedangkan gizi kurang $7,39 \%$, gizi sangat kurang $1,40 \%$, dan gizi lebih 2,69\%. Angka tersebut memiliki nilai yang tinggi jika dibandingkan yang lain. Namun, perbandingan keseluruhan malnutrisi antar wilayah belum dapat terukur akibat indeks yang belum terintegrasi.

Stunting, underweight, overweight dan wasting merupakan kategori hasil pengukuran dari indeks antropometri konvensional untuk mengukur status kekurangan gizi. Indeks pengukuran antropometri lainnya adalah Composite Index of Antrophometric Failure. Composite Index of Anthropometric Failure (CIAF) adalah suatu indeks alternatif untuk pengukuran kegagalan status gizi. Hasil dari kategori tersebut akan diakumulasi menjadi satu kesatuan nilai indeks yang mencerminkan seluruh prevalensi malnutrisi. ${ }^{7}$

Pengukuran status gizi dengan Indeks konvensional (tunggal) tidak dapat menentukan prevalensi keseluruhan malnutrisi dan tidak dapat mendeteksi anak dengan malnutrisi ganda karena mengharuskan untuk memilih salah satu kategori kegagalan antropometri untuk mewakili status gizi populasi yang menjadi sasaran. Berkaitan dengan hal ini, maka tidak dapat diramalkannya beban malnutrisi pada suatu wilayah dan resiko kesakitan dan kematian. Solusinya adalah pengukuran dengan menggunakan Composite Index of Anthropomeric Failure (CIAF). Hasil dari kategori tersebut akan diakumulasi menjadi satu kesatuan nilai indeks yang 
mencerminkan seluruh prevalensi malnutrisi. Pengukuran CIAF serta faktor-faktor yang mempengaruhinya selama ini belum pernah dilakukan di wilayah puskesmas Karangayu.

Berdasarkan penjelasan di atas, tujuan penelitian ini adalah menganalisis faktor-faktor yang mempengaruhi status gizi balita pada usia 0-23 bulan berdasarkan Composite Index of Anthropometric Failure (CIAF) di wilayah kerja Puskesmas Karangayu.

\section{Metode}

Penelitian ini merupakan penelitian observasional analitik dengan cross-sectional sebagai desain studi. Variabel yang diteliti pada penelitian ini adalah variabel bebas berupa usia anak, jenis kelamin, berat badan lahir, panjang badan lahir, status gizi ibu saat hamil, usia ibu saat hamil, tinggi badan ibu saat hamil, usia kehamilan ibu bersalin, status pekerjaan ibu, dan tingkat pendidikan. Sedangkan variabel terikat pada penelitian ini adalah status gizi pada anak usia 0-23 bulan. Analisis data yang dilakukan meliputi analisis univariat dan analisis bivariat. Uji statistik yang digunakan menggunakan uji Chi-Square dan Fisher Exact.

Penelitian ini dilaksanakan pada bulan Mei- September 2019 di wilayah kerja Puskemas Karangayu. Teknik pengambilan sampel menggunakan total sampling. Sampel yang didapatkan yaitu sebanyak 231 ibu dengan anak usia 0-23 bulan menggunakan penentuan minimal besar sampel berdasarkan metode slovin. Minimal sampel yang didapatkan sebesar 220.

Adapun kriteria inklusi penelitian ini adalah ibu yang memiliki anak dengan usia 0 23 bulan; memiliki buku KIA; berdomisili di wilayah kerja Puskesmas Karangayu; bersedia untuk menjadi responden dalam penelitian ini. Kriteria eksklusi penelitian ini adalah data atau informasi yang diberikan tidak lengkap.

\section{Hasil}

Distribusi malnutrisi ini akan digambarkan berdasarkan CIAF dengan mempertimbangkan komponen usia anak, berat badan, dan panjang badan anak.

Tabel 1. Distribusi Status Gizi Berdasarkan CIAF

\begin{tabular}{clrr}
\hline \multirow{2}{*}{ Kelompok } & \multicolumn{1}{c}{ Keterangan } & $\begin{array}{c}\text { Jumlah } \\
(\mathbf{n})\end{array}$ & $\begin{array}{c}\text { Persentase } \\
(\%)\end{array}$ \\
\hline A & Status gizi normal & 152 & 65.8 \\
B & Status gizi wasting & 10 & 4.3 \\
C & Status gizi wasting dan & 5 & 2.2 \\
underweight & Status gizi wasting, stunting, dan & 1 & 0.4 \\
D & underweight & 12 & 5.2 \\
E & Status gizi stunting dan & 25 & 10.8 \\
F & underweight & 5 & 2.2 \\
H & Status gizi stunting & 19 & 8.2 \\
Y & Status gizi stunting dan overweight & 2 & 0.9 \\
\hline Total & Status gizi overweight & 231 & 100 \\
\hline
\end{tabular}


Tabel 2. Distribusi Frekuensi Berdasarkan Variabel Penelitian

\begin{tabular}{|c|c|c|}
\hline Variabel & $\mathbf{n}$ & $\%$ \\
\hline \multicolumn{3}{|l|}{ Usia } \\
\hline $0-6$ bulan & 71 & 30.7 \\
\hline $7-23$ bulan & 160 & 69.3 \\
\hline \multicolumn{3}{|l|}{ Jenis Kelamin } \\
\hline Perempuan & 117 & 50.6 \\
\hline Laki-Laki & 114 & 49.4 \\
\hline \multicolumn{3}{|l|}{ Berat Badan Lahir } \\
\hline BBLR & 10 & 4.3 \\
\hline Tidak BBLR & 221 & 95.7 \\
\hline \multicolumn{3}{|l|}{ Panjang Badan Lahir } \\
\hline PBLP & 45 & 19.5 \\
\hline Tidak PBLP & 186 & 80.5 \\
\hline \multicolumn{3}{|l|}{ Statuts Gizi Ibu } \\
\hline KEK & 28 & 12.1 \\
\hline Tidak KEK & 203 & 87.9 \\
\hline \multicolumn{3}{|l|}{ Usia Ibu Saat Hamil } \\
\hline Beresiko $(<20$ tahun dan $>35$ tahun $)$ & 26 & 11.3 \\
\hline Tidak Beresiko (20-35 tahun) & 205 & 88.7 \\
\hline \multicolumn{3}{|l|}{ Tinggi Badan Ibu Saat Hamil } \\
\hline Pendek $(<150 \mathrm{~cm})$ & 26 & 11.3 \\
\hline Tidak Pendek ( $\geq 150 \mathrm{~cm})$ & 205 & 88.7 \\
\hline \multicolumn{3}{|l|}{ Usia Kehamilan Ibu Bersalin } \\
\hline Preterm $(<37$ minggu $)$ & 11 & 4.8 \\
\hline Aterm $(\geq 37$ minggu $)$ & 220 & 95.2 \\
\hline \multicolumn{3}{|l|}{ Status Pekerjaan Ibu } \\
\hline Bekerja & 131 & 56.7 \\
\hline Tidak Bekerja & 100 & 43.3 \\
\hline \multicolumn{3}{|l|}{ Tingkat Pendidikan Ibu } \\
\hline Tinggi & 176 & 76.2 \\
\hline Akademi/Perguruan Tinggi & 67 & 29.0 \\
\hline SMA/sederajat & 109 & 47.2 \\
\hline Rendah & 55 & 23.8 \\
\hline SMP/sederajat & 42 & 18.2 \\
\hline $\mathrm{SD} /$ sederajat & 12 & 5.2 \\
\hline Tidak Sekolah & 1 & 0.4 \\
\hline
\end{tabular}


Tabel 3. Hasil Analisis Bivariat

\begin{tabular}{|c|c|}
\hline Variabel & p-value \\
\hline Usia Anak $\left.^{*}\right)$ & 0.029 \\
\hline Jenis Kelamin & 0.997 \\
\hline Berat Badan Lahir & 0.316 \\
\hline Panjang Badan Lahir ${ }^{*}$ & 0.005 \\
\hline Status Gizi Ibu saat Hamil & 0.232 \\
\hline Usia Ibu saat Hamil*) & 0.002 \\
\hline Tinggi Badan Ibu saat Hamil) & 0.025 \\
\hline Usia Kehamilan Ibu Bersalin*) & 0.049 \\
\hline Status Pekerjaan Ibu & 0.614 \\
\hline Tingkat Pendidikan & 0.951 \\
\hline
\end{tabular}

${ }^{*}$ Faktor yang berhubungan $(p$-value $<0.05)$

\section{Pembahasan}

Berdasarkan indikator tunggal antropometri, penelitian ini memperoleh proposi anak anak dengan stunting (22.9\%), overweight (11.6\%), underweight $(9.5 \%)$, dan wasting (7.4\%). Proporsi CIAF lebih besar jika dibandingkan dengan indikator konvensional yakni sebesar $34.2 \%$. Indikator konvensional tidak dapat mengidentifikasi prioritas dalam permasalahan malnutrisi dan anak dengan malnutrisi ganda. Perhitungan tunggal menyebabkan tumpang tindih dalam pengelompokkan sehingga tidak dapat menggambarkan keadaan malnutrisi yang sebenarnya. Pengukuran BB/U, $\mathrm{PB} / \mathrm{U}$, dan $\mathrm{BB} / \mathrm{PB}$ merupakan komponen yang saling bergantung satu dengan yang lain. $\mathrm{BB} / \mathrm{U}$ dapat mengindikasi malnutrisi akut dan kronis, namun keduanya tidak dapat dibedakan akibat perhitungan yang tumpang tindih. Hal tersebut berpotensi memberikan intervensi yang tidak tepat. Manajemen malnutrisi bergantung pada jenis malnutrisi yang diderita, penyebabnya, dan tingkat keparahannya. ${ }^{8}$ Sebagai contoh, anak dengan underweight dan stunting namun memiliki berat badan dan tinggi badan tergolong normal, maka pemberian PMT (Pemberian Makanan Tambahan) merupakan tindakan yang kurang tepat karena anak berpotensi untuk menjadi gemuk. ${ }^{9}$

Penemuan dalam penelitian ini menunjukan bahwa anak dengan malnutrisi lebih banyak ditemui pada anak usia 7-23 bulan dibandingkan dengan anak usia 0-6 bulan. Beberapa penelitian menunjukan hal yang sama, bahwa anak yang lebih tua cenderung mengalami malnutrisi dibandingkan anak yang lebih muda. ${ }^{10}$ Usia transisi dari ASI eksklusif, yakni 0-13 bulan, menuju pemberian makanan tambahan merupakan faktor yang berkontribusi kepada tingginya kejadian malnutrisi secara global. ${ }^{11}$ Hal tersebut dikarenakan adanya gap antara kebutuhan dan tidak terpenuhinya energi dan nutrisi yang diperlukan tubuh. Meningkatnya usia semakin meningkatkan kebutuhan tubuh akan nutrisi dan energi, sehingga harus diiringi dengan asupan yang semakin tinggi. Kejadian tersebut tidak berdiri sendiri, namun didukung karakteristik keluarga seperti keadaan sosial ekonomi, pola asuh, serta pengetahuan orang tua mengenai kebutuhan nutrisi pada anak. Rendahnya pengetahuan mengenai pemenuhan asupan tubuh berkontribusi lebih besar dibandingkan kurangnya ketersediaan pangan karena perlu mempertimbangkan antara frekuensi dan jumlah pemberian makan. ${ }^{12}$

Hasil uji menunjukkan tidak ada hubungan antara jenis kelamin perempuan dan laki-laki. Hal ini sejalan dengan beberapa penelitian lainnya. Pada dasarnya, laki-laki memiliki kebutuhan nutrisi tubuh lebih besar daripada perempuan. Hal ini terlihat dari variasi ukuran tubuh yang berbeda berdasarkan kurva pertumbuhan. Perempuan cenderung tumbuh lebih cepat dibandingkan laki-laki, dan puncak 
pertumbuhan laki-laki lebih lambat dibandingkan perempuan.

Meskipun tidak ada hubungan yang signifikan antar status berat badan lahir dengan status gizi baduta, namun proporsi anak BBLR yang terkena malnutrisi lebih besar dibandingkan anak BBLR tanpa malnutrisi. Indikator ini telah menjadi prediktor dalam pertumbuhan bayi. Banyak pasien yang lahir dengan BBLR tidak memiliki etiologi yang jelas. Namun, faktor ibu dan anak telah diidentifikasi sebagai faktor penyebab BBLR dengan korelasi yang kuat. Faktor maternal berkorelasi terhadap tidak memadainya pasokan nutirisi ke janin. Kurangnya asupan makanan ibu, penyakit sistemik seperti diabetes, atau fungsi plasenta yang abnormal menjadi faktor mayoritas yang merujuk kepada gangguan kehamilan, terutama pada trimester ketiga. Penelitian lain menemukan faktor tidak langsung yang mendukung kelahiran BBLR seperti hubungan paritas, etnis, dan usia yang beresiko menjadi faktor yang berperan dalam kelahiran anak BBLR. Paparan rokok, penggunaan alkohol, dan obat-obatan terlarang berkontribusi mengganggu perkembangan janin. Paparan rokok berkontribusi 3.24 kali lebih beresiko untuk melahirkan anak BBLR. ${ }^{13}$

Beberapa penelitian menunjukan hasil yang sama bahwa panjang badan memiliki hubungan yang signifikan dengan status gizi anak, namun hubungan ini berkorelasi kuat dengan kejadian stunting. ${ }^{14}$ Panjang badan lahir dipengaruhi oleh tinggi badan ibu. Anak yang lahir dengan panjang lahir pendek membuat anak harus mengejar ketertinggalan tinggi badannya yang seringkali tidak diiringin dengan asupan nutrisi yang cukup.

Pengukuran lingkar lengan atas dapat memberikan gambaran kondisi jaringan otot dan lapisan lemak kulit untuk memperkirakan kelahiran bayi BBLR pada ibu hamil. ${ }^{9}$ KEK pada ibu dapat dinilai dengan mengukur lingkar lengan atas. Apabila seseorang mengalami KEK, maka ia telah kekurangan energi dalam jangka waktu bulan hingga tahunan (kronis). Risiko ibu dengan KEK berpeluang lebih tinggi untuk kesulitan persalinan, pendarahan, dan melahirkan bayi BBLR akibat tidak terpenuhinya nutrisi yang dibutuhkan. Sebesar 50\% kejadian KEK ini mempengaruhi kasus tingginya BBLR. ${ }^{15}$ Anak dengan BBLR akan membutuhkan nutrisi lebih untuk dapat mengejar kebutuhan agar dapat tumbuh dengan optimal, namun seringkali hal ini tidak dibarengi dengan asupan yang adekuat sehingga beresiko lebih tinggi untuk mengalami malnutrisi. Berbagai penelitian juga telah menunjukan bahwa KEK pada ibu memiliki hubungan terhadap kejadian malnutrisi pada anak balita. ${ }^{16,17}$

Ibu hamil dibawah usia 20 tahun memiliki resiko 8 kali lebih besar memiliki anak stunting, 3 kali lebih besar memiliki anak wasting, dan 13 kali lebih besar memiliki anak underweight dibandingkan ibu hamil dengan usia tidak beresiko. ${ }^{18}$ Penyebab utama untuk menjelaskan hal tersebut masih menjadi perdebatan. Sebagian menyebutkan bahwa faktor fisiologis dan anatomi, namun sebagian lain menyebutkan faktor yang berkontribusi adalah status sosial ekonomi, dukungan sosial, perawatan antenatal yang kurang baik, hingga faktor lainnya seperti budaya. $^{19}$ Studi menjelaskan faktor feto-maternal mengenai zat gizi merupakan penyebab langsung yang meningkatkan resiko kelahiran prematur, sehingga ibu muda disarankan untuk merencanakan kehamilan setelah masa pertumbuhannya selesai. Untuk menentukan faktor mana yang paling berpengaruh dalam studi ini diperlukan analisis lebih lanjut. Usia ibu diatas 35 tahun juga memiliki resiko tinggi untuk memiliki anak dengan malnutrisi. ${ }^{20}$ Sama halnya dengan risiko ibu dibawah 20 tahun, penyebab utama masih menjadi perdebatan karena karakteristik diberbagai wilayah yang berbeda serta kegagalan dalam pengendalian variabel perancu dalam penelitian. Namun, ibu diatas 35 tahun memiliki resiko lebih tinggi mengalami komplikasi yang disebabkan oleh beberapa penyakit seperti diabetes, preeklampsia, dan hipertensi. Faktor tersebut meningkatkan risiko kelahiran BBLR dan premature hingga anak berisiko tinggi menjadi malnutrisi. ${ }^{21}$

Penelitian ini sejalan dengan sebuah studi yang menyatakan bahwa tinggi badan ibu berkorelasi dengan kejadian malnutrisi, terutama pada anak stunting. ${ }^{22}$ Penelitian mengenai hubungan tinggi badan ibu dan pola pertumbuhan anak pada empat tahap masa 
pertumbuhan memperoleh bahwa tinggi badan saat dewasa secara kuat berkorelasi dengan proses pada 1000 hari pertama kehidupan serta merupakan akumulasi dari faktor genetik dan lingkungan. Fisik ibu akibat tinggi yang rendah cenderung memiliki organ reproduksi yang kecil, sehingga memiliki ruang yang lebih sempit untuk janin tubuh. Semakin tinggi usia bayi dalam kandungan, maka kebutuhan akan protein dan energi meningkat. Namun, akibat uterus yang kecil, penyimpanan untuk protein dan energi menjadi terbatas. Akibatnya, pertumbuhan anak menjadi tidak optimal. ${ }^{23}$

Patofisiologi yang menjelaskan kejadian prematur masih belum jelas. Etiologi mengenai hal ini bervariasi seperti faktor maternal, faktor fetal, serta berbagai faktor eksternal mencakup keadaan sosial ekonomi dan budaya. Kelahiran prematur menyebabkan beberapa kerugian diantaranya adalah koordinasi reflek menghisap ASI yang kurang baik, minimnya kemampuan mencerna glukosa, kapasitas lambung yang cenderung lebih kecil, serta imunitas yang belum memadai. Akibatnya, terdapat berbagai hambatan untuk penyerapan nutrisi yang dibutuhkan dalam tubuh serta beban kebutuhan nutrisi yang lebih tinggi dibandingkan usia kehamilan bersalin yang normal. Sebuah penelitian menemukan bahwa ibu yang melahirkan anak dengan preterm mengandung jumlah lemak dan laktosa lebih sedikit dibandingkan ibu yang melahirkan anak aterm, namun protein lebih banyak pada ibu yang melahirkan preterm dibandingkan ibu yang melahirkan aterm. ${ }^{24}$ Penelitian ini sejalan dengan beberapa penelitian lainnya.

Hasil penelitian sejalan dengan beberapa penelitian lainnya. ${ }^{25,10}$ Namun, tidak sejalan dengan penelitian lain yang menyatakan bahwa pekerjaan ibu memiliki hubungan dengan status gizi. Hal ini karena ibu yang bekerja dianggap memiliki waktu yang lebih sedikit untuk mengasuh dan memberikan perhatian kepada anaknya. Baik status ibu bekerja atau tidak, keduanya diharuskan untuk memahami perkembangan dan pertumbuhan anak sehingga tumbuh-kembangnya optimal. ${ }^{26}$

Hasil yang menunjukan tidak adanya hubungan mengenai tingkat pendidikan ibu dan status gizi anak baduta memungkinkan bahwa ibu dengan pendidikan yang tinggi memiliki kecenderungan untuk kurang mampu mengimplementasikan pengetahuannya mengenai gizi pada anak. Adapun informasi mengenai status gizi dapat diperoleh tidak hanya dari pendidikan formal saja, namun juga fasilitas kesehatan seperti puskesmas dan posyandu, serta melalui internet. ${ }^{27,25,10}$

\section{Kesimpulan}

Faktor yang berhubungan dengan status gizi anak 0-23 bulan berdasarkan CIAF adalah usia anak, panjang lahir, usia ibu saat hamil, tinggi badan ibu, dan usia kehamilan ibu bersalin. Sedangkan yang tidak berhubungan adalah berat lahir, pekerjaan ibu, pendidikan ibu, jenis kelamin, dan status gizi ibu. Faktor dominan dari variabel yang diteliti adalah usia ibu saat hamil. Diharapkan penelitian selanjutnya dapat meneliti faktor resiko yang lebih spesifik agar akar masalah dari malnutrisi dapat diketahui.

\section{Ucapan Terima Kasih}

Terima kasih kepada Dinas Kesehatan Kota Semarang, Puskesmas Karangayu, kader posyandu serta responden yang bersedia berpartisipasi pada penelitan ini sehingga penelitian ini dapat terlaksana dengan baik.

\section{Daftar Pustaka}

1. Kemenkes RI. Kumpulan dari beberapa istilah dan pengertian yang berhubungan dengan Kesehatan [Internet]. [cited 2019 Apr 16]. Available from: http://www.depkes.go.id/index.php?txtKey word=status+gizi\&act=searchbymap\&pgn umber $=0 \&$ charindex $=\&$ strucid $=1280 \&$ full content $=1 \& C A L L=1$.

2. Renyoet BS, Martianto D, Sukandar D. Potensi kerugian ekonomi karena stunting pada balita di indonesia tahun 2013. Gizi Pangan. 2016;11 (November):247-54.

3. Global Nutrition Report. Global nutrition report: shining a light to spur action on nutrition [Internet]. 2018. Available from: http://ebrary.ifpri.org/cdm/ref/ collection/p 15738 coll2/id/128484. 
4. UNICEF, WHO WB. Prevalence of underweight, weight for age (percentage of children under 5) [Internet]. 2019 [cited 2018 Apr 17]. Available from: https://data.worldbank.org/indicator/sh.sta. maln.zs.

5. UNICEF, WHO, World Bank Group. Levels and trends in child malnutrition: key findings of the 2018 edition of the joint child malnutrition estimates. 2018.

6. Semarang DKK. Profil kesehatan kota semarang 2017. Semarang; 2012.

7. Nandy S. The composite index of anthropometric failure (CIAF): an alternative indicator for malnutrition in young children. in: handbook of anthropometry: physical measures of human form in health and disease [Internet]. Bristol: Springer Science Business Media; 2012. p. 127-37. Available from:http://link.springer.com/1 0.1007/978-1-4419-1788-1.

8. Shahrin L, Chisti MJ, Ahmed T. Primary and secondary malnurition. World Rev Nutr Diet. 2015;113(April):139-46.

9. Adisty AC. Nutritional care process. Yogyakarta: Graha Ilmu; 2012. 240 p.

10. Ramadani CA. kekurangan gizi pada anak balita berdasarkan composite index of anthropometric failure (CIAF) di Provinsi Nusa Tenggara Barat Tahun 2010 (Analisis Data Riskesdas 2010). Universitas Indonesia; 2012.

11. Kahsay M, Tuba T, Belete Y, Muleta A, Tadesse N. Nutritional status of under two years old infants in the pastoral community of Somali Regional State, Ethiopia : Case of Awbare District. 2018;8(3):65-71.

12. Arisman. Buku ajar ilmu gizi: gizi dalam daur kehidupan. 2nd ed. Jakarta: Penerbit Buku Kedokteran EGC; 2010.

13. Negrato CA, Brito Gomes M. Erratum: Low birth weight: Causes and consequences (Diabetology and Metabolic Syndrome). Diabetology and Metabolic Syndrome 2014;6(1):1.
14. Lamana A, Julia M, Dasuki D. Korelasi tinggi badan ibu dengan panjang badan bayi baru lahir di Kota Palu. Kesehatan Reproduksi. 2017;4(2):103-8.

15. Ariyani DE. Validitas Ukuran Lingkar lengan atas terhadap indeks massa tubuh dalam mendeteksi risiko kekurangan energi kronis pada wanita (20-45 tahun) di Indonesia (Analisis Data Riskesdas 2007). Universitas Indonesia; 2012.

16. Ricalde AE, Velásquez-Meléndez $\mathrm{G}$, Tanaka ACDA, De Siqueira AAF. Midupper arm circumference in pregnant women and its relation to birth weight. Rev Saude Publica. 1998;32(2):112-7.

17. Saputra M. Hubungan antara riwayat bayi berat lahir rendah (BBLR) dengan status gizi pada anak balita di Kelurahan Pringgokusuman, Kecamatan Gedongtengen, Kota Yogyakarta. Universitas Muhammadiyah Surakarta; 2012.

18. Wemakor A, Garti H, Azongo T, Garti H, Atosona A. Young maternal age is a risk factor for child undernutrition in Tamale Metropolis, Ghana. BMC Res Notes [Internet]. 2018;11(1). Available from: https://doi.org/10.1186/s13104-018-39807.

19. Kang G, Lim JY, Kale AS, Lee LY. Adverse effects of young maternal age on neonatal outcomes. Singapore Medical Journal. 2015;56(3):157-63.

20. Fall CHD, Sachdev HS, Osmond C, Restrepo-Mendez MC, Victora C, Martorell R. Association between maternal age at childbirth and child and adult outcomes in the offspring: a prospective study in five low-income and middleincome countries (COHORTS collaboration). Lancet Global Health. 2012;3(7):341-422.

21. Kahveci B, Melekoglu R, Evruke IC, Cetin C. The effect of advanced maternal age on perinatal outcomes in nulliparous singleton pregnancies. Pregnancy and Childbirth. 2018;18(343):1-7. 
22. Ferreira HS, Moura FA, Ju CRC, Vieira RC, Assunc ML De. Short stature of mothers from an area endemic for undernutrition is associated with obesity, hypertension and stunted children: a population-based study in the semi-arid region of Alagoas, Northeast Brazil. 2009;1239-45.55 Addo OY, Stein AD, Fall CH, Gigante DP, Guntupalli AM, Horta BL, et al. Maternal Height and Child Growth Patterns. J Pediatr [Internet]. 2013;163(2):549-554.e1. Available from: http://dx.doi.org/10.1016/j.jpeds.2013.02.0 02 .

23. Addo OY, Stein AD, Fall CH, Gigante DP, Guntupalli AM, Horta BL, et al. Maternal height and child growth patterns. Journal Pediatric [Internet]. 2013;163(2):549554.e1. Available from: http://dx.doi.org/10.1016/j.jpeds. 2013.02 .002 .

24. Narang APS, Bains HS, Kansal S, Singh D. Comparative study of trace elements of human milk in preterm and term mothers. Trace Elem Electrolytes [Internet]. 2006;23(2):99-102. Available from: http://embase.com/search/results?subactio $\mathrm{n}=$ viewrecord $\&$ from $=$ export $\& \mathrm{id}=\mathrm{L} 436520$ 72 .
25. Senthilkumar SK, Chacko T V, Suvetha K. Nutritional status assessment of children aged 0-5 years and its determinants in a tribal community of Coimbatore district. 2018;5(7):2835-45.

26. Utina J, Palamani S, Tamunu E.. Periode penting dalam tumbuh kembang. 2012;1(1):18-22.

27. Rozali NA, Subagyo B, Widhiyastuti E. Peranan pendidikan, pekerjaan ibu dan pendapatan keluarga terhadap status gizi balita di posyandu RW 24 dan 08 wilayah kerja Puskesmas Nusukan Kota Surakarta. 2016; Available from: http://eprints.ums.ac.id/41781/1/Naskah_P ublikasi_Nur_Azikin_Rozali.pdf. 